\title{
FITOTERAPIA
}

Fitoterapia 75 (2004) 795-798

www.elsevier.com/locate/fitote

Phytochemical communication

\section{A new sesquiterpene from the fruits of Allophylus laevigatus}

\author{
Juceni P. David ${ }^{\mathrm{a}, *}$, Ihanmarck D. dos Santos ${ }^{\mathrm{b}}$, Jorge M. David ${ }^{\mathrm{b}}$ \\ ${ }^{\mathrm{a}}$ Faculdade de Farmácia, Universidade Federal da Bahia, Campus Ondina, 40170-290, Salvador, Bahia, Brazil \\ ${ }^{\mathrm{b}}$ Instituto de Quimica, Universidade Federal da Bahia, 40170-290, Salvador, Bahia, Brazil \\ Received 26 November 2003; accepted in revised form 9 September 2004
}

\begin{abstract}
From the fruits of Allophylus laevigatus a new sesquiterpene, 11-acetoxy- $4 \alpha$-methoxyeudesmane, was isolated alongwith the known compounds carissone and apigenin- $8-\mathrm{C}-\beta$-rhamnopyranoside. The flavone showed no antioxidant activity in the autoxidation of $\beta$-carotene assay. (C) 2004 Elsevier B.V. All rights reserved.

Keywords: Eudesmane sesquiterpenes; Allophylus laevigatus; Apigenin-8-C- $\beta$-rhamnopyranoside
\end{abstract}

\section{Plant}

Allophylus laevigatus, fruits collected in January 1998 in the "restinga" of Parque Metropolitano de Pituaçu, Salvador (Bahia), Brazil. The plant material was identified by Prof. Germano Guarim Neto of Universidade Federal do Mato Grosso (UFMT) and a voucher was deposited under number 042618 in Herbarium Alexandre Leal Costa, Instituto de Biologia, Universidade Federal da Bahia.

A. laevigatus Radlk is a tree belonging to the family Sapindaceae, which possesses 140 genera distributed in the tropical and subtropical areas [1]. In Brazil the species of this family are distributed in 22 different genera, most of them in the Amazon region

* Corresponding author. Tel.: +55 71 3321580; fax: +55 712355166.

E-mail address: juceni@ufba.br (J.P. David).

0367-326X/\$ - see front matter (C) 2004 Elsevier B.V. All rights reserved. doi: $10.1016 /$ j.fitote. 2004.09 .018 
(especially the genera Sapindus, Serjania, Cardiospermum and Paullinia [2]). The genus Allophylus is represented in the northwest of Brazil where were reported the occurrence of A. dioicus Radlk, A. laevigatus Radlk, A. semidentatus Radlk, A. puberulus Radlk, A. quercifolius (Mart.) Radlk, A. edulis (A. St.-Hil.) Radlk, A. petiolulatus Radlk and $A$. sericeus Radlk.

\section{Uses in traditional medicine and other reported activities}

Many species of the genera Allophylus and Sapindus are used in Brazil in folk medicine [1]. Only A. edulis was reported to contain sesquiterpenes [3], flavonoids and phenolic compounds [4].

\section{Previous isolated constituents}

No constituents described from this species.

\section{New-isolated constituents}

Carissone (1, $11.8 \mathrm{mg}$, from $826 \mathrm{~g}$ of dried fruits) [5], the new compound (2, $15.3 \mathrm{mg})$ and $3-\beta-O$-glycopyranosylsitosterol $(49.7 \mathrm{mg})$ were isolated from the $\mathrm{CHCl}_{3}$ phase obtained from $\mathrm{MeOH}$ extract (118 g) after Si-Gel CC and PTLC.

Compound 2 showed spectral data consistent with an eudesmane skeleton carrying a methoxy and an acetoxyl groups ( $\delta 3.12$ and 1.97 in the ${ }^{1} \mathrm{H}-\mathrm{NMR}$ spectrum). The quasi molecular ion at $m / z 314\left[\mathrm{M}+\mathrm{NH}_{4}^{+}\right]$detected by CI-MS permitted to assign the molecular formula $\mathrm{C}_{18} \mathrm{H}_{32} \mathrm{O}_{3}$ to this compound. Inspection of the NMR spectra allowed to identify compound 2 as a methyl ether of 11 -acetoxyeudesman- $4 \alpha$-ol [6]. The correlations between the hydrogens (H-14) of methyl group at $\delta 1.04$ with $\mathrm{C}-4(\delta 76.1), \mathrm{C}-3$ ( $\delta 44.8)$ and C-5 (50.1) and the correlation between the methoxyl group ( $\delta 3.12)$ and $\mathrm{C}-4$ at $\delta 76.1$ were conclusive of the presence of methoxyl group at C-4 position. On the other hand, the correlations observed for hydrogens of the two methyl groups $(\delta 1.42$ and 1.45$)$ and $\mathrm{C}-7$ ( $\delta$ 47.2) and C-11 ( $\delta$ 85.1) indicated $\mathrm{C}-11$ as bearing the acetoxy group.

Besides these compounds, apigenin-8-C- $\beta$-rhamnopyranoside 3, (19.2 mg) [7] was isolated from the methanolic extract (Fig. 1) alongwith the known sitosterol (24.4 mg), stigmasterol $(23.9 \mathrm{mg})$ and stigmast-4-en-3-one (14.4 mg). A mixture of fatty acids (555.7 $\mathrm{mg}$ ), found by GC-MS analysis to contain tetradecanoic, hexadecanoic and 9hexadecenoic acids, was also isolated.

The antioxidant activity of $\mathbf{3}$ was determined by the method described by Hidalgo [8], based on the inhibition of autoxidation reaction of $\beta$-carotene/linoleic acid system. Compound 3 had little pro-oxidant activity ( $\mathrm{AA}=19.4)$ when compared to the propyl gallate $(\mathrm{AA}=55.7)$, $\mathrm{BHT}(\mathrm{AA}=72.5)$ and $\alpha$-tocopherol $(\mathrm{AA}=43.5)$.

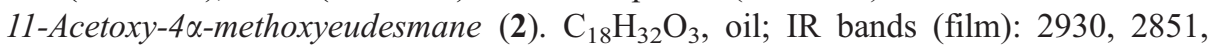
$1731,1458,1384,1367,1256,1126 \mathrm{~cm}^{-1} ;{ }^{1} \mathrm{H}-\mathrm{NMR}\left(300 \mathrm{MHz}, \mathrm{CDCl}_{3}\right): \delta 0.89(3 \mathrm{H}, s, \mathrm{H}-$ 
<smiles>CC1=C2CC(C(C)(C)O)CCC2(C)CCC1=O</smiles><smiles>COC(C)(C)C1CCC2(C)CCC[C@](C)(OC)C2C1</smiles>

1<smiles>O=c1cc(-c2ccc(O)cc2)oc2c([14OH])c(O)cc(O)c12</smiles>

Fig. 1. Isolates from A. laevigatus.

15), 1.05 (3H, $s, \mathrm{H}-14), 1.42$ (3H, $s, \mathrm{H}-12), 1.45$ (3H, $s, \mathrm{H}-13), 1.97$ (3H, $s, \mathrm{Ac}), 3.12(3 \mathrm{H}$, $s$, OMe); CI-MS $m / z$ (rel. int.): 314 [(M+NH $\left.)_{4}{ }^{+}(56)\right], 237$ (30), $205(100) ;{ }^{13} \mathrm{C}-\mathrm{NMR}(75$ $\left.\mathrm{MHz}, \mathrm{CDCl}_{3}\right): \delta 19.1$ (C-14), 19.2 (C-15), 19.7 (C-2), 21.1 (C-6), 22.1 (C-8), 22.5 (OOCMe), 23.5 (C-13), 23.7 (C-12), 34.5 (C-10), 36.1 (C-10), 40.8 (C-1), 44.8 (C-3), 47.1 (C-7), 47.6 (OMe), 50.1 (C-5), 76.1 (C-4), 85.1 (C-11), 170.5 (COO).

Apigenin-8-C- $\beta$-rhamnopyranoside (3). Yellow powder; UV $\max (\mathrm{MeOH}): 276$ (15380) and $330(11355) \mathrm{nm},\left(\mathrm{MeOH}+\mathrm{AlCl}_{3}\right): 278$ and $373 \mathrm{~nm},(\mathrm{MeOH}+\mathrm{NaOMe}): 279$ and $389 \mathrm{~nm}$, (MeOH+NaOAc): 280 and $382 \mathrm{~nm} ;{ }^{1} \mathrm{H}-\mathrm{NMR}\left(300 \mathrm{MHz}, \mathrm{CDCl}_{3}\right): \delta 1.28$ $\left(3 \mathrm{H}, d, 5.4 \mathrm{~Hz}, \mathrm{H}-6^{\prime \prime}\right), 4.53\left(1 \mathrm{H}, d, 8.9 \mathrm{~Hz}, \mathrm{H}-1^{\prime \prime}\right), 6.64(1 \mathrm{H}, s, \mathrm{H}-6), 6.77(1 \mathrm{H}, s, \mathrm{H}-3)$, $6.92\left(2 \mathrm{H}, d, 8.0 \mathrm{~Hz}, \mathrm{H}-3^{\prime}\right.$ and $\left.\mathrm{H}-5^{\prime}\right), 7.91\left(2 \mathrm{H}, d, 8.0 \mathrm{~Hz}, \mathrm{H}-2^{\prime}\right.$ and $\left.\mathrm{H}-6^{\prime}\right) ;{ }^{13} \mathrm{C}-\mathrm{NMR}$ $\left(100 \mathrm{MHz}, \mathrm{CDCl}_{3}\right)$ : $\delta 163.9$ (C-2), 102.8 (C-3), 182.3 (C-4), 156.8 (C-5), 99.2 (C-6), 163.8 (C-7), 103.8 (C-8), 156.3 (C-9), 102.9 (C-10), 121.2 (C-1' ), 128.1 (C-2' , C-6' ), $116.2\left(\mathrm{C}-3^{\prime}, \mathrm{C}-5^{\prime}\right), 161.2\left(\mathrm{C}-4^{\prime}\right), 78.5\left(\mathrm{C}-1^{\prime \prime}\right), 73.6\left(\mathrm{C}-2^{\prime \prime}\right), 73.1$ (C-3"), $71.4\left(\mathrm{C}-4^{\prime \prime}\right)$, $70.5\left(\mathrm{C}-5^{\prime \prime}\right), 18.5\left(\mathrm{C}-6^{\prime \prime}\right)$.

\section{Acknowledgements}

The authors are grateful to the Conselho Nacional de Desenvolvimento Científico e Tecnológico (CNPq) and Fundação Coordenação de Aperfeiçoamento de Pessoal de Nível Superior (CAPES) for grants and fellowship supports. We are in debt with Dr. G.A. Cordell for MS data and Dr. G. Guarim Neto for the plant identification.

\section{References}

[1] Hegnauer W. Sapindaceae. Chemotaxonomie Pflanz 1970;6:271.

[2] Joly AB. Botânica: Introdução à Taxonomia Vegetal, Companhia Ed. Nacional 11 a ed., 1993.

[3] Fester GA, Retamar JA, Ricciardi AI. Bol Acad Nac Cienc (Cordoba, Rep Arg) 1960;42:13. 
[4] Arisawa M, Morinaga Y, Nishi Y, Ueno H. Shoyakugaku Zasshi 1989;43:78.

[5] Maatoog GT, Stumpf DK, Hoffmann JJ, Hutter LK, Timmermann BN. Phytochemistry 1996;41:519.

[6] Su W-C, Fang J-M, Cheng Y-S. Phytochemistry 1995;39:603.

[7] Haggag EG, Mahmoud II, Abou-Moustafa EA, Mabry TJ. Asian J Chem 1999;11:707.

[8] Hidalgo ME, Fernández E, Quilhot W, Lissi E. Phytochemistry 1994;37:1585. 